\title{
Attitiude towards Mathematics and Achademic Achievement in Mathematics among Secondary Level Boys and Girls
}

\author{
${ }^{1}$ Sarwat Mubeen, ${ }^{2}$ Dr.Safia Saeed, ${ }^{3}$ Col. Dr. Manzoor Hussain Arif \\ ${ }^{I}$ (Department of Education, Foundation University College of Liberal Arts and Sciences, Pakistan) \\ ${ }^{2}$ (Department of Education, University of Wah, Wah Cantt.pakistan) \\ ${ }_{3}^{3}$ (Foundation University College of Liberal Arts and Sciences, Pakistan)
}

\begin{abstract}
Attitudes towards are the important determinants of academic success and achievement. In order to succeed in a subject, positive attitude towards a subject is a necessary prerequisite. This also applies to mathematics, especially in case of girls as compared to boys.

The main purpose of the study was to measure relationship of attitude towards mathematics with academic achievement in math among $9^{\text {th }}$ and $10^{\text {th }}$ class secondary level students. Sample of the study consisted of 500 students out of which 200 were boys and 300 were girls. This sample was chosen from two girls' and two boys schools in wah cantt (Pakistan). The secondary students were mostly of 15 and 16 years age group. A 25item questionnaire was self developed in the light of available literature on the subject and adaptation of another instrument, developed by Steinback and Gwizdala. Academic achievement was measured by the marks obtained by the sample in their recently held examination in mathematics in their school. The obtained data were analyzed and interpreted using statistical tool of correlation coefficient.

The result show that boys differed in their mathematical achievement from girls. Girls achieved better results as compared to boys. Attitude towards mathematics and achievement in math did not go together.
\end{abstract}

Keywords: Attitude, Mathematics, Academic Achievement, Secondary Education

\section{Introduction}

Mathematics education is to a nation what protein is to a young human organism. As a vital tool for the understanding and application of science and technology. The choice of this topic is predicated on the current world trends and research emphasis on gender differences in learning of mathematics.

According to Reid (2006), attitudes express our evaluation of something or someone. They are based on our knowledge, feelings and behavior and they may influence future behavior. A target is essential for attitude. Our attitude is always directed towards something or someone. Attitudes are highly composite and they can affect learning comprehensively. Attitudes influence performance and performance in turn influences attitudes including attitudes.

Attitude will affect behavior, influencing what the learner selects from the environment, how he will react towards teachers, towards the material being used and towards the other students. This selection and the processing of the input of information, which follow it, are strongly influenced among other things on attitudes. There are four broad areas where we might wish to explore attitudes in relation to students.

- Attitudes toward subjects being studied;

- Attitudes towards study itself;

- Attitudes towards the implications arising from themes being studied;

- The so-called scientific attitudes

In general, attitudes in life allow us to:

a) Make sense of ourselves;

b) Make sense of the world around us;

c) Make sense of relationships.

A very useful analysis was carried out by Perry (1999), and this has led to a useful framework for analyzing students' attitude to work under the four headings:

a) Student's perceptions about the nature of knowledge;

b) Student's perceptions about the role of the lecturer in their learning;

c) Student's perceptions about their own role in learning;

d) Student's perceptions about the nature and role of assessment.

Gender differences in mathematics and science education to try to determine whether females are less capable of doing mathematics than males. Math is as much a social issue as an educational issue. The educational issues are: 1) The way in which students are taught mathematics and science and 2) The way in which students are tested as well as the testing producers and questions. The social issue is what students learn in their social environments, i.e., at home or in the workplace. Examining the roots of gender differences in 
learning may help find a solution to the problem that women are dramatically under represented in mathematics and science-based careers (Hyde and McKinley 1996).

One of the most common explanations for gender disparities in mathematics achievement has focused on attitude that students have towards mathematics. Several studies have reported that there are gender differences in attitude towards mathematics with girls showing more negative attitudes than boys. In general, most of the studies reported that, compared with boys, girls lacked confidence, had debilitating causal attribution patterns, perceived mathematics as a male domain, and were anxious about mathematics (Vermeer $e t$ $a l, 2000)$. The causes of the gender difference were found to be multifaceted.

Fisher and Rickards (1998) found that students' attitude towards mathematics tended to be more positive in classroom where students perceived greater leadership and helping/friendly behaviors in their teachers, and more negative in their classrooms where students perceived their teachers as admonishing and enforcing strict behaviors. Other researchers have compared the effect of separate (single-sex) and coeducational classrooms upon students' attitude (Norton and Rennie, 1998).

Studies that compared gender differences in mathematics' self confidence have mostly reported that girls had lower self-confidence in mathematics than boys (Case et al, 1997; Norton and Rennie, 1998). In some cases, boys were more confident than girls even when their mathematics achievement was similar to that of girls (Casey et al, 1997). Vermeer et al (2000) have further shown that the gender differences in self confidence were more marked for application problems than computation problems, with girls showing significantly lower confidence for application problem.

Despite such consistent findings of girls' low confidence in mathematics, studies of classroom environment have shown that the girls' confidence in mathematics improved greatly in classes which actively involved girls in the learning of mathematics (Boaler, 2000).

Bono (1991) in his study girls would enjoy math, increase their time on math tasks, and have positive emotional reactions to math if math were taught in a cooperative setting. The study explored the impact of cooperative learning on sixth grade girls. The results showed that girls had more positive attitudes towards math when it was taught in cooperative settings.

As far as differences in attitude development are concerned, girls' positive attitudes towards mathematics decline as they grow older. Initially girls have more positive attitudes towards mathematics than boys, but as they continue in school, girls' attitudes become more negative. In order to improve girls' performance in math, teachers need to facilitate positive attitude in girls towards math. (Swetman, 1995).

Usual indications about the girls reveal that they are week in mathematics as compared to boys. Many studies done on the topic in the foreign countries. But in Pakistan, the studies are very few. In fact, teachers and parents may be responsible for low achievement of girls' in mathematics. Many teachers, especially female, actively encourage males to persist in mathematics than girls. Parents also feel that girls have less inclination for this subject because of its difficulty and complexity. It requires also extra attention, stamina and intelligence in which girls never come up to the standard.

Since learners engaging in mathematics activities (including participating in mathematics competitions are affected by external and internal influences on their perceptions and attitudes towards mathematics, it was felt that an investigation into the relationship between attitude toward math and performance in mathematics was important. Gender related difference in attitudes towards mathematics was also investigated.

The objectives of the study were:

1. To examine gender differences in attitude towards mathematics and academic achievement towards math.

2. To find out the relationship between attitude towards mathematics and academic achievement in mathematics.

In this study, following null hypotheses were tested at 0.05 level of significance:

1. There is no significant difference between mean attitude scores of secondary level boys and girls towards mathematics.

2. There is no significant difference between mean achievement scores of secondary boys and girls in the subject of math.

3. There is no significant relationship between attitude scores towards mathematics and academic achievement of secondary level girls.

4. There is no significant relationship between mean attitude scores towards mathematics and academic achievement of secondary level boy.

The study hypotheses were tested through t-test and product moment technique. Correlation coefficient to the relationship among variables of attitude and academic achievement. 


\section{Research Method}

\subsection{Sample}

A sample of 500 students was selected through two-stage cluster sampling. The procedure of selecting sample was that, at the first stage four schools two boy's schools and two girls' schools were randomly selected. Then 300 girls and 200 boys were randomly chosen from these schools.

\section{2 Research Instrument}

The research design of this study was questionnaire survey .In order to measure the variable of attitude of students towards mathematics, a 25 -item questionnaire was self developed in the light of available literature on the subject another instrument, developed by Steinback and Gwizdala. Each item was to be responded on a three point scale bearing the categories of agree, disagree and undecided. Questionnaire adequately represented the construct of attitude towards math. For facilitating the respondents, the questionnaire was translated into Urdu. In addition, six items were included about the bio data of each student such as name of the students, class, family size, birth order, socio economic background (upper, lower, middle).

\section{3 Scoring of Data}

The student responses on each item were scored by using the score of 1 for 'disagree', 2 for 'undecided' and 3 for 'agree'. The aggregate attitude scores were calculated for each student by adding the marks on each item of the questionnaire.

\section{Results}

Table 1: Significance of Difference between Mean Attitude towards Mathematics Score among Secondary Level Boys and Cirls.

\begin{tabular}{|l|l|l|l|l|l|l|}
\hline Groups & N & Mean & SD & SE & t & P \\
\hline Girls & 300 & 57.67 & 0.45 & 0.24 & 12.71 & $<.05$ \\
Boys & 200 & 60.72 & 0.27 & & & \\
\hline
\end{tabular}

df: 498 t at .05 level: 1.960

Table 1 shows the obtained $t$ value is 12.71 whereas the table value at .05 level of significance showing the real difference between mean attitude scores of boys and girls in mathematics is, therefore significant, so there is difference between mean attitude scores of boys and girls in mathematics.

Table 2: Significance of Difference between Mean Achievement towards Mathematics Score among Secondary Level Boys and Girls.

\begin{tabular}{|l|l|l|l|l|l|l|}
\hline Groups & N & Mean & SD & SE & t & p \\
\hline Girls & 300 & 54.04 & 1.01 & 160.27 & 02 & $>.05$ \\
Boys & 200 & 57.00 & 0.85 & & & \\
& & & & & & \\
\hline
\end{tabular}

df: $498 \quad t$ at .05 level: 1.960

Table 2 shows the obtained $\mathrm{t}$ value is .02 whereas the table value at .05 level of significance showing the real difference between mean achievement scores of boys and girls in mathematics is, therefore non significant, so there is no difference between mean attitude scores of boys and girls in mathematics.

Table 3: Significance of Correlation between Attitude Scores towards Mathematics and Achievement Scores in Mathematics with respect to Secondary Level Girls.

\begin{tabular}{|l|l|l|l|}
\hline Variables & N & r & p \\
\hline Attitude Achievement & 300 & 0.32 & $<.05$ \\
& \multicolumn{2}{|c|}{ r at .05 level: 1946} \\
\hline
\end{tabular}

Table 3 illustrates, the correlation coefficient between attitude scores and academic achievement scores of the total sample students of girls belonging to Government schools of girls in Wah Cantt was .32 whereas the table value of correlation coefficient was .1946 at .05 level of significance. The correlation coefficient between the variable of attitude and academic achievement was, therefore significant. 
Table 4: Significance of Correlation between Attitude Scores towards Mathematics and Academic Achievement Scores in Mathematics with respect to Secondary Level Boys.

\begin{tabular}{|l|l|l|l|}
\hline Variables & $\mathrm{N}$ & $\mathrm{r}$ & $\mathrm{p}$ \\
\hline Attitude Achievement & 200 & 0.13 & $>.05$ \\
\hline \multicolumn{2}{|c|}{ df: 198} & $\mathrm{r}$ at .05 level: .1946
\end{tabular}

Table 4 illustrates, the correlation coefficient between attitude scores and academic achievement scores of the total sample students of girls belonging to Government schools of boys in Wah Cantt was .13 whereas the table value of correlation coefficient was .1946 at .05 level of significance. The correlation coefficient between the variable of attitude and academic achievement was, therefore non significant.

\section{Conclusion And Discussion}

The Study has revealed following points:

In general, female students tended to show better performance towards mathematics in examinations as compared to male students. Though there is positive correlation between attitude towards mathematics and math achievement but the relationship was significant only in case of girls. In the group of boys, the coefficient of correlation could not reach significant value.

The result show that boys differed in their mathematical achievement from girls. Girls achieved better results as compared to boys. Attitude towards mathematics and achievement in math did not go together. Some previous studies also support the present study's results as Sinnes (2005), is agree that females in principle will produce exactly the same scientific knowledge as males provided that sufficient rigour is undertaken in scientific inquiry. Abiam and Odok (2006) found no significant relationship between gender and achievement in number and numeration, algebraic and statistics. On the contrary, Opolot-Okurut (2005) found that for all the attitudinal variables (anxiety, confidence and motivation), males had higher mean scores than females. That is, the differences in student attitude towards mathematics based on gender were confirmed.

A lot need to be done to fill this gender gap in mathematics achievement. Male and female students should make the competitive environment, coordinate and exchange their knowledge from one another in mathematics teaching and learning. Girls students should be informed the importance of mathematics and it is the basic tool for further education.

Mathematics teaching and evaluation strategies should be bias-free. This way, males and females will tend to see themselves as equals, capable of competing and collaborating in classroom activities.

\section{References}

[1] N. Ried, Getting Started in Pedagogical Research in the Physical Sciences, Higher Education Academy Physical Sciences Centre, University of Glasgow, UK, 2006, 32-60.

[2] W. G. Perry, Forms of intellectual and ethical development in the college years: a scheme. Jossey-Bass Higher and Adult Education Series, 1999.

[3] Hyde and McKinley, 1996. Gender Differences in Human Cognition, books.google.com.pk/books?isbn, 1996, 132.

[4] H.Vermeer, M. Boekaerts, and G.Seegers, Motivational and gender differences: Sixth- grade students' mathematical problem solving behavior. Journal of Educational Psychology, 92(2), 2000, 308-315.

[5] D. Fisher, and T. Rickards, Associations between teacher-student interpersonal behavior and student attitude towards mathematics. Mathematics Education Research Journal, 10(1), 1998, 3-15.

[6] S.J. Norton, and 1. J. Rennie, Students attitude towards mathematics in single-sex and Co- educational schools. Mathematics Educational Research Journal, 10(1), 1998, 16-36

[7] M.B. Casey, R.L. Nuttalla, and E. Pezaris, Mediators of Gender Differences in Mathematics College Entrance Test Scores: A Comparison of Special Skills with Internalized Beliefs and Anxieties. Developmental Psychology 33(4), 1997, 669-680.

[8] J. Boaler, So girls don't really understand mathematics? Dangerous dichotomous in gender research. Paper Presented at the $9^{\text {th }}$ International Conference of Mathematics Education (ICME-9), 2000, Tokyo.

[9] D. Bono, The impact of cooperative learning on suzy and janie's attitude about math/research report in Virginia, 1991, 137-167.

[10] D. Swetman, Rural Elementary Students' attitudes toward mathematics, rural education. International Journal of Computer Technology and Application V.16 no.3, 1995, 20-22.

[11] A. T. Sinnes, Approaches to gender equity in science education. Two initiatives in sub-saharan african seen through a lens derived fromfeministcritiqueofscience.Oslo:2005,htt//www.ils.u10.no/forskininig/palidgrade/doktorarhandlinger/docs/AstridSinnes/Avhand ling feminist critique of science.oslo: Unipub.pdf.

[12] P. O. Abiam, and , j. k. Odok, Factors in students' achievement in different branches of secondary school mathematics. Journal of Education and Technology 1(1), 2006, 161-168.

[13] C. Opolot-Okurot, Student attitude towards mathematics in uganda secondary schools, African Journal of Research in Mathematics, Science and Technology in Education, 9(2),2005, 167-174. 